\title{
Mathematical Analysis of How the Electrical Training Center Site is Affected by Air Pollution
}

\author{
Bassam A. Al-Helou \\ Department of Engineering and Technology, \\ Faculty of Engineering, Technology-Zarqa University, P.O. Box 132222 Zarqa, 13132, Jordan
}

Received 2012-07-18, Revised 2012-08-31; Accepted 2012-09-03

\begin{abstract}
The study has come to the result that the monitoring site at the Electrical Training Centre (ETC) at AlHashimyeh town is exposed to grave pollution that goes beyond Jordanian standards of the ambient air. It has, indeed, shown that Sulfur dioxide $\left(\mathrm{SO}_{2}\right)$ exceeds the limits and its seasonal concentration matches forward with the average wind speed. $\mathrm{SO}_{2}$ concentration reaches its lowest level in the early morning of the day and its highest level at the end of the day. The study has also pointed out that the levels of carbon oxides do not exceed the Jordanian standards of the ambient air and that the mathematical analysis indicators have pointed to the continuing increase of nitrogen oxides due to the increase of calm winds year after year. In fact, these winds do not help the dispersal and decrease of emissions; on the contrary, they increase the emissions concentration, especially in the areas approximate to the pollution sources.
\end{abstract}

Keywords: Air Pollution, Concentration, Sulfur Dioxide, Carbon Oxides, Nitrogen Oxides, Jordanian Standard, Wind Speed, Mathematical Modeling, Wind Direction

\section{INTRODUCTION}

The aim of this study is to identify the degree of air pollution at the ETC resulting from some major pollution sources, such as the Jordanian Petroleum Refinery (JPR) and Al Hussein Thermal Power Plant (HTPP), in addition to the pollution emanating from the emissions of the transport routes and the numerous factories available at Al-Hashimyeh in Zarqa Governorate.

This exactly means that the pollution affecting the ETC monitoring site is the outcome of the activities of oil refinery and electrical power generation in the region, in addition to the pollution caused by the vehicles movement on the roads (JPRC, 2011; HTPP, 2001; ME, 2010; MiE, 2010; Hamdi et al., 2008). The urban population of Jordan has increased from $64 \%$ of the total in 1980 to $74 \%$ in 2000 (Reay, 2004). AlHashimyeh area is located north of Zarqa city, $35 \mathrm{~km}$ northeast of Amman. It is bounded by Longitude $36^{\circ}$ $04^{\prime}$ to $39^{\circ} 09^{\prime}$ east and Latitude $32^{\circ} 04^{\prime}$ to $32^{\circ} 10^{\prime}$ north. This town is the most polluted city in Jordan (Odat, 2009; DEAZ, 2005).

It is well-known that exposure for long to pollutants or dust causes health damages. However, health disadvantages would be much greater if man is simultaneously exposed to higher levels of more than one pollutant, namely $\mathrm{SO}_{2}, \mathrm{NO}, \mathrm{NO}_{2}$ and dust. Health damages especially affect children, elders and people stricken by allergy, chest diseases, asthma, (Peters et al., 1997; WHO, 2005; Mage and Zali, 1992; Seaton et al., 1995; APPA, 1998).

The following pollutants are monitored: sulfur dioxide, carbon dioxide, carbon monoxide and nitrogen oxides.

Sulfur dioxide $\left(\mathrm{SO}_{2}\right)$ is a poisonous gas. It agitates the tissues of eyes, noses, pharynxes and lungs. So once absorbed by a human body, $\mathrm{SO}_{2}$ operates as an internal toxin that would possibly impair the nervous and respiratory systems. $\mathrm{SO}_{2}$ is a colorless gas and so cannot be visible when it infiltrates. Neither can it be seen in a stormy weather. It moves as an invisible cloud, usually in the wind direction. It is a heavier gas than air and tends to fall on low lands, such as ditches, drainages and holes, where it goes well as a fatal gas. The degree of $\mathrm{SO}_{2}$ effect depends on its concentration in air, as well as on the victim's allergy and exposure duration. So if $\mathrm{SO}_{2}$ condensation in air amounts to $100 \mathrm{ppm}$, it then develops eye and throat inflammation, headache, nausea, cough and the olfaction becomes useless within 3-15 min (Burki et al., 1994; Jol and Kielland, 1997; Lefohn and Shadwick, 1998; Kalabokas et al., 1999; WHO, 1979). The degree of $\mathrm{SO}_{2}$ condensation in air is based on the quantity of fuel consumption and the ratio of sulfur in there. 
Table 1. Some Pollutants Concentration Limits in Jordan, Standard 1140/2006 Jordanian Standards, 2006

\begin{tabular}{llll}
\hline & Average exposure & Concentration & \\
Pollutant & Time & Limit $(\mathrm{ppm})$ & Number of allowed exceeds \\
\hline $\mathrm{SO}_{2}$ & $1 \mathrm{~h}$ & 0.30 & Three times within any 12 months \\
$\mathrm{SO}_{2}$ & $24 \mathrm{~h}$ & 0.14 & One time within a year \\
$\mathrm{SO}_{2}$ & Annual & 0.04 & - \\
$\mathrm{CO}$ & $1 \mathrm{~h}$ & 26.00 & Three times within any 12 months \\
$\mathrm{CO}$ & $8 \mathrm{~h}$ & 9.00 & Three times within any 12 months \\
$\mathrm{NO}_{2}$ & $1 \mathrm{~h}$ & 0.21 & Three times within any 12 months \\
$\mathrm{NO}_{2}$ & $24 \mathrm{~h}$ & 0.08 & Three times within any 12 months \\
$\mathrm{NO}_{2}$ & yearly & 0.05 & -
\end{tabular}

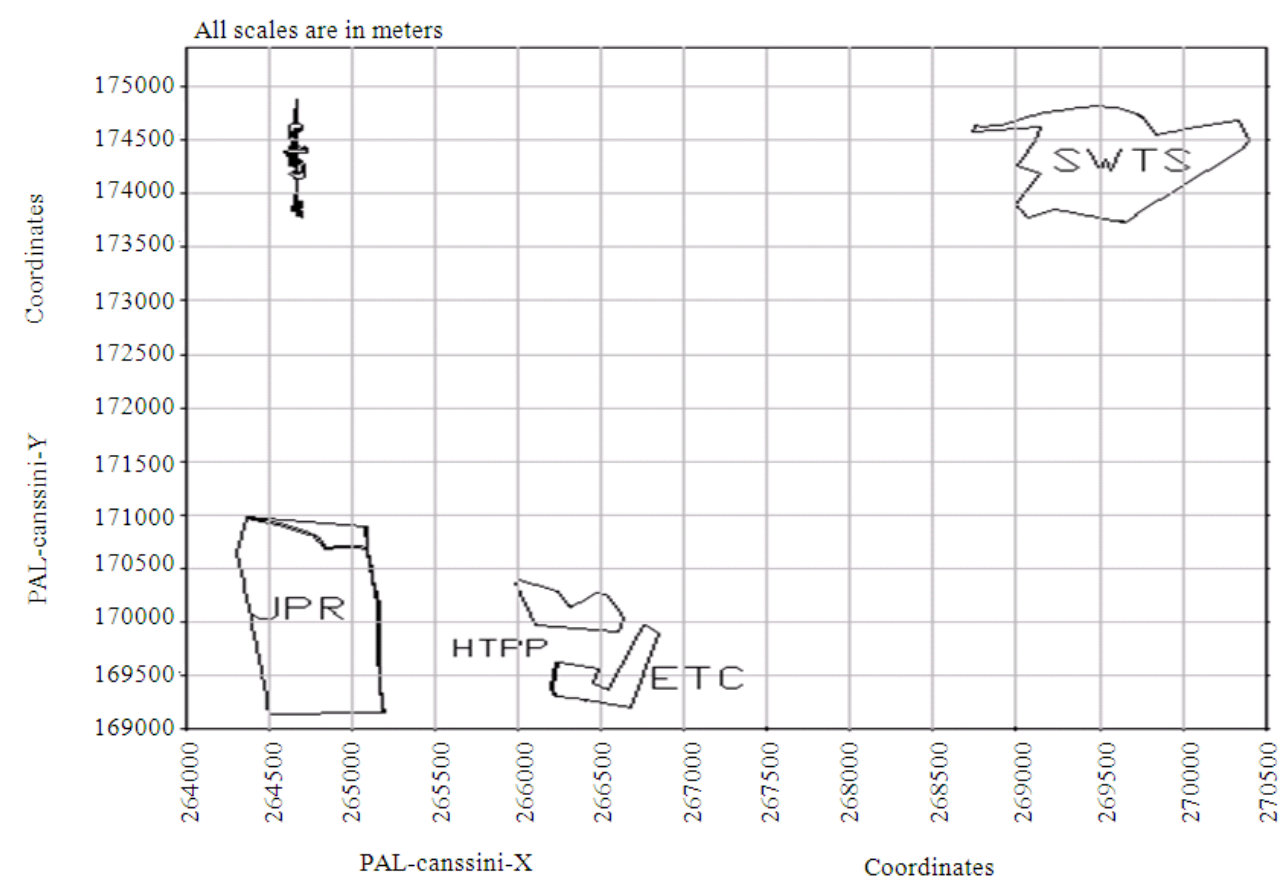

Fig. 1. The geographical locations of the monitoring site and the pollution sources

Carbon Monoxide (CO) is a gas with no color or smell. It emanates from the incomplete combustion interaction of hydrocarbon fuel. However, the main source of this gas is the traffic movement on road, especially the benzeneoperating vehicles. In fact, the $\mathrm{CO}$ affecting danger on man lies in its potential of creating carboxyl hemoglobin in man's blood, which really causes man's blood inability to carry oxygen to his organs. As such, it exposes to further danger those people who suffer from the inefficiency of extending oxygen to heart and brain (e.g., patients of coronary artery) (Al-Helou and Sinokrot, 2004; WHO, 2005; Brunekreef and Holgate, 2002; DH, 2005).

Nitrogen Oxides $\left(\mathrm{NO}_{\mathrm{x}}\right)$, the term used to describe the sum of $\mathrm{NO}$ and $\mathrm{NO}_{2}$, play a major role in the formation of tropospheric ozone can also contribute to the formation of acid rain (Jol and Kielland, 1997; Mbuyi, 2003). Long-term exposures (e.g., one year) to nitrogen oxide concentrations may damage forest and vegetation (Fally et al., 1995). Nitrogen oxides are formed in hightemperature combustion processes, mainly in petrol and diesel vehicles (Monroe and $\mathrm{Li}, 2002$ ). The pollutants have been checked in this study within the limits determined by the Jordanian standards of the ambient air (Table 1).

\subsection{Air Monitoring Site}

Al-Hashimyeh ETC Monitoring site lies only $2 \mathrm{kms}$ to the south-east of JPR, $0.25 \mathrm{~km}$ south-east HTPP and about $5.5 \mathrm{kms}$ south-west Samra Wastewater Treatment Station (SWTS) (Fig. 1). 


\subsection{Monitoring Procedures}

The air samples are analyzed for Carbon Oxides (CO and $\left.\mathrm{CO}_{2}\right)$ concentrations using analyzer Infrared Fluorescence, Nitrogen Oxides $\left(\mathrm{NO}, \mathrm{NO}_{\mathrm{x}}\right.$ and $\mathrm{NO}_{2}$ ) concentrations using analyzer Chemiluminescence. The $\mathrm{SO}_{2}$ analyze done using Ultra-Violent Fluorescence. The Wind speed and direction are measured using a MetroUnit. Additionally, meteorological data are collected at the Zarqa weather station. Wind speed, wind direction, ambient temperature, barometric pressure and solar radiation are measured hourly.

\subsection{Sulfur Dioxide $\left(\mathrm{SO}_{2}\right)$}

ETC is affected by the $\mathrm{SO}_{2}$ emission from the JPR and HTPP stations. Both stations constitute to be the consistent sources of sulfur dioxide that emanates from fuel combustion and oil refinery in Al-Hashimyeh area. In addition, the fact that sulfur dioxide contains high degree of sulfur which is carried by west and North West winds, at a range of about $950 \mathrm{ppm}$, although the European Standard set by $50 \mathrm{ppm}$ (OPEC, 2005).

Figure 2 shows that on January 6, 2010, the monitoring results of $\mathrm{SO}_{2}$ in that year had registered $\mathrm{SO}_{2}$ 's highest level of $1.766 \mathrm{ppm}$ and those 783 cases of exceeding the Jordanian standard limits 1140/2006 were, in average, $0.3 \mathrm{ppm}$, i.e. by $8.93 \%$. Moreover, these monitoring results had shown that the max daily average was $0.623 \mathrm{ppm}$ and that the exceeding daily averages of those limits by $0.14 \mathrm{ppm}$ were 68 , i.e., $18.634 \%$.

Figure 3 shows the direction of wind distribution at the time of the daily exceeding of the Jordanian standards. This exactly clarifies the great pollution danger by $\mathrm{SO}_{2}$ which the monitoring site is exposed to as west has winds increased to $20.1 \%$, North West winds to $21.7 \%$ and calm winds to $30.7 \%$. All together, those winds amounted to $72.5 \%$ a very high degree of wind accumulation that permanently exposes the monitoring site to $\mathrm{SO}_{2}$ pollution.

Table 2 shows the max recorded average in each of the monitored months. The average exceeds were recorded throughout those monitored months. The table also shows that calm winds had recorded high proportions of pollution during those months as a whole, which actually means that these winds do not disperse or reduce the emissions produced by HTPP. Rather they increase their concentration. This table clearly shows that the west and North West winds are relatively abundant and are capable to carry the emissions from JPR and HTPP to the monitoring site and subsequently increased $\mathrm{SO}_{2}$ concentration there.

Figure 4 shows the monthly average of $\mathrm{SO}_{2}$ concentrations; its lowest level was in March and the $\max$ in June at a rate of 0.010 and $0.159 \mathrm{ppm}$ respectively. It also clearly proves an exceeding to the $0.14 \mathrm{ppm}$ limit of the Jordanian standards.
Figure 5 shows the annual and seasonal average of $\mathrm{SO}_{2}$ concentrations and the wind speed in each hour of the day. It can be noted that the $\mathrm{SO}_{2}$ concentration fits forward with the wind speed average. It actually reaches its lowest level in the early morning and to its highest level at the end of the day. Air tranquility plays an important role in the distance which the wind may reach and in its concentration in the surrounding air as well.

Comparing the 2010 monitoring results with the previous ones, i.e. the results measured in: 2004-2005, 2005-2006, 2006-2007, 2007-2008 and in 2009 it becomes clearly obvious that 2010 results are the highest since 2006-2007 and the numbers of excessive averages were between 246 and 951. The highest excess was, indeed, in 2004-2005, while the highest average values ranged between 0.813 and $6.545 \mathrm{ppm}$, (the latter being registered in 2004-2005). It is also noted that the percentage of the excess averages began their progressive increase since $2007-2008$ up to 2010 . In 2006 , they recorded an increase of 3.13 and $8.93 \%$ in 2010 (Fig. 6).

Figure 7 shows the daily averages of $\mathrm{SO}_{2}$ concentration during the period of monitoring from 2004 to 2010 . The maximum daily average was recorded in 2009 at $1.192 \mathrm{ppm}$ and that the number of excesses ranged between 24-115, the highest of which was in 2004-2005 and the lowest was in the monitoring period of 2006-2007.

The above- mentioned analysis points clearly to the excesses, in the monitoring site, of the Jordanian standard limits of $\mathrm{SO}_{2}$ and that those excesses were emphatically noted throughout the years of monitoring. The percentages of those excesses underline the need for taking necessary measures of reducing, as much as possible, the sulfur quantity in fuel before it is burnt and for installing systems to treat the discharged air from chimneys before it darts into the ambient air.

\subsection{Carbon Oxides $\left(\mathrm{CO}, \mathrm{CO}_{2}\right)$}

HTPP and JPR constitute the main and constant sources of $\mathrm{CO}$ and $\mathrm{CO}_{2}$ emission that results from the fuel combustion and refining. $\mathrm{CO}_{2}$ is generated from the full process of combustion, whereas $\mathrm{CO}$ is generated from the incomplete process of burning, especially when starting operation and halting the units of production.

The results of 2010 monitoring show that no excess to the $\mathrm{CO}$ average limits as determined by the Jordanian standards at $26 \mathrm{ppm}$, knowing that Jordanian standards contain no item regarding $\mathrm{CO}_{2}$. Table 3 shows the maximum hourly averages of $\mathrm{CO}$ and $\mathrm{CO}_{2}$ concentrations. It also shows the maximum 8-hours averages of $\mathrm{CO}$ concentrations. No excess to limits as determined by the Jordanian standards at $9 \mathrm{ppm}$ was noted. 
Bassam A. Al-Helou / American Journal of Applied Sciences 9 (11) (2012) 1840-1848

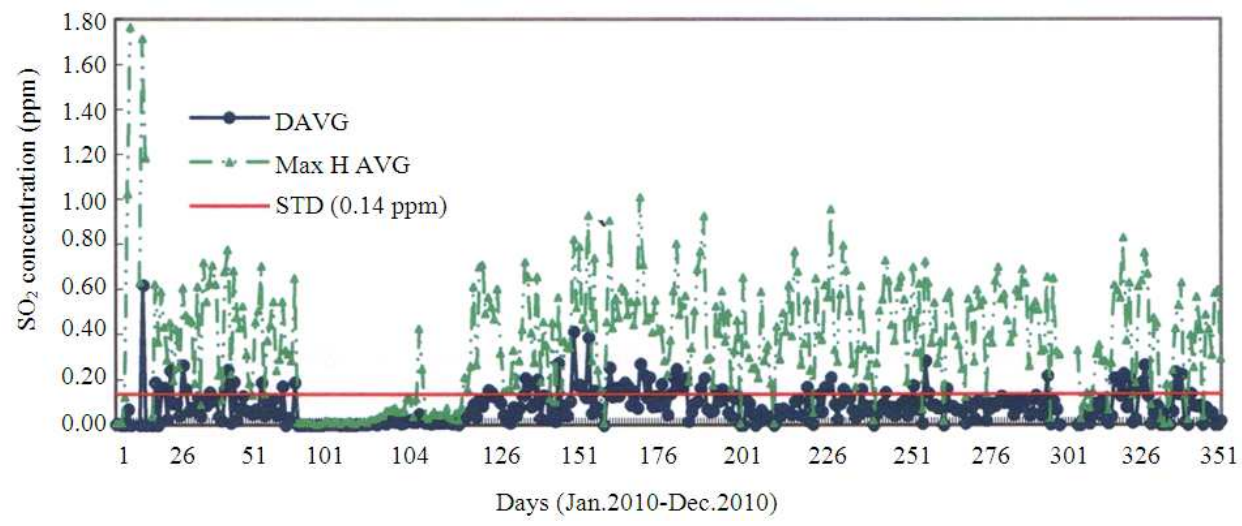

Fig. 2. Daily averages and max hourly averages concentrations of $\mathrm{SO}_{2}$ at ETC

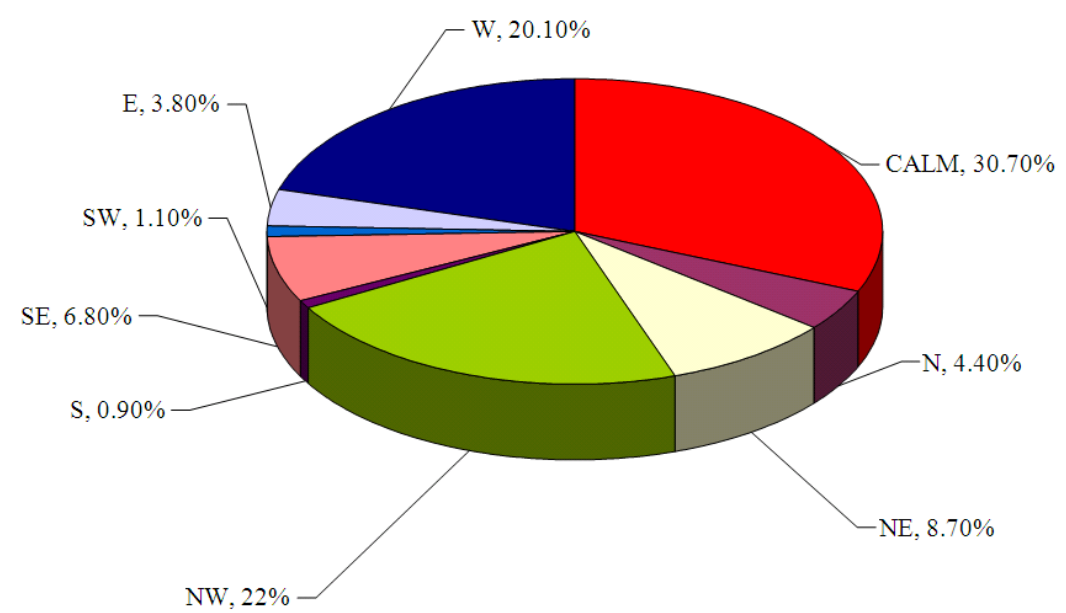

Fig. 3. Wind direction distribution during days at which $\mathrm{SO}_{2}$ daily average concentration exceeded JS limit at ETC

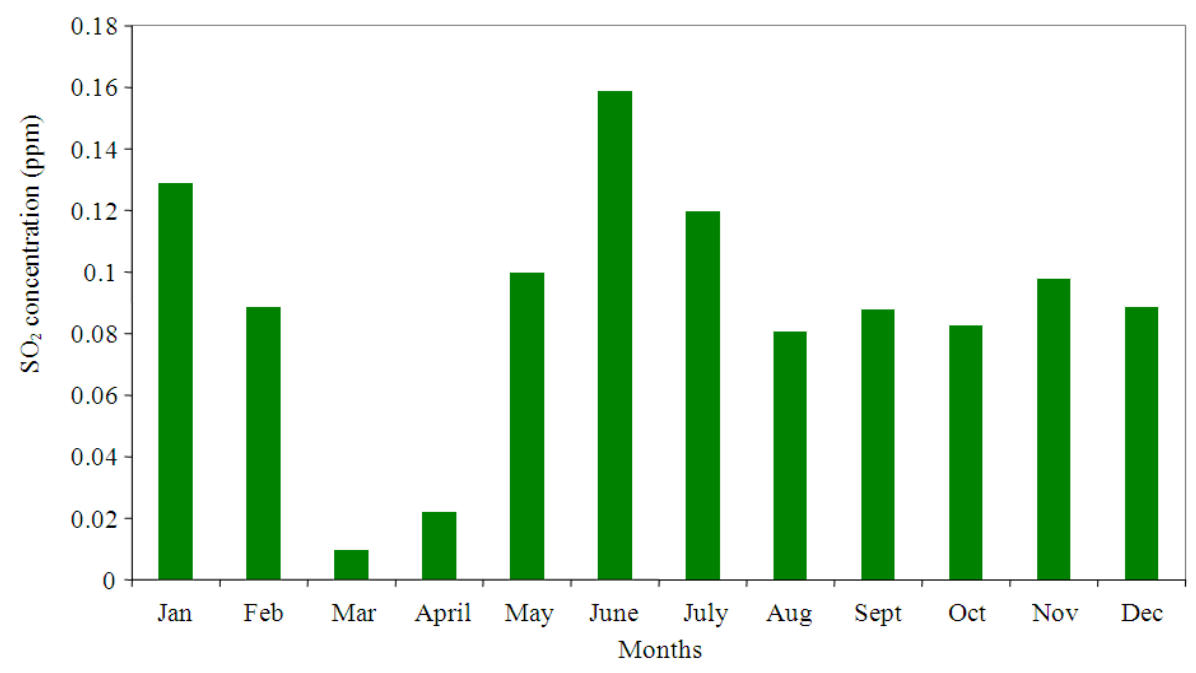

Fig. 4. Monthly averages concentrations of $\mathrm{SO}_{2}$ at ETC 
Bassam A. Al-Helou / American Journal of Applied Sciences 9 (11) (2012) 1840-1848
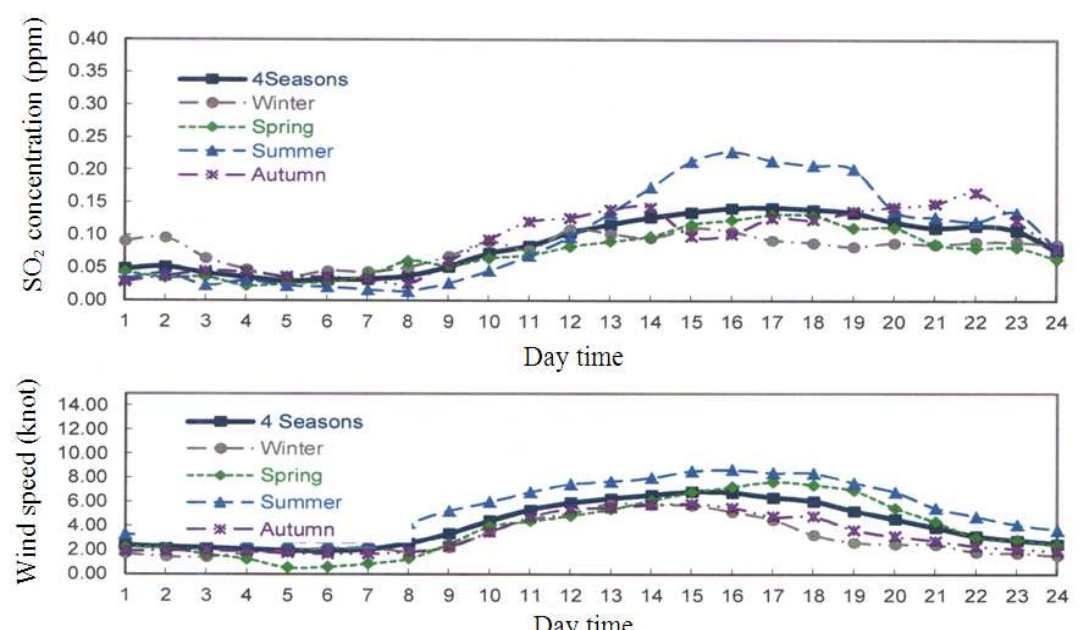

Fig. 5. Averages diurnal concentrations of $\mathrm{SO}_{2}$ and wind speed diurnal average (knot)

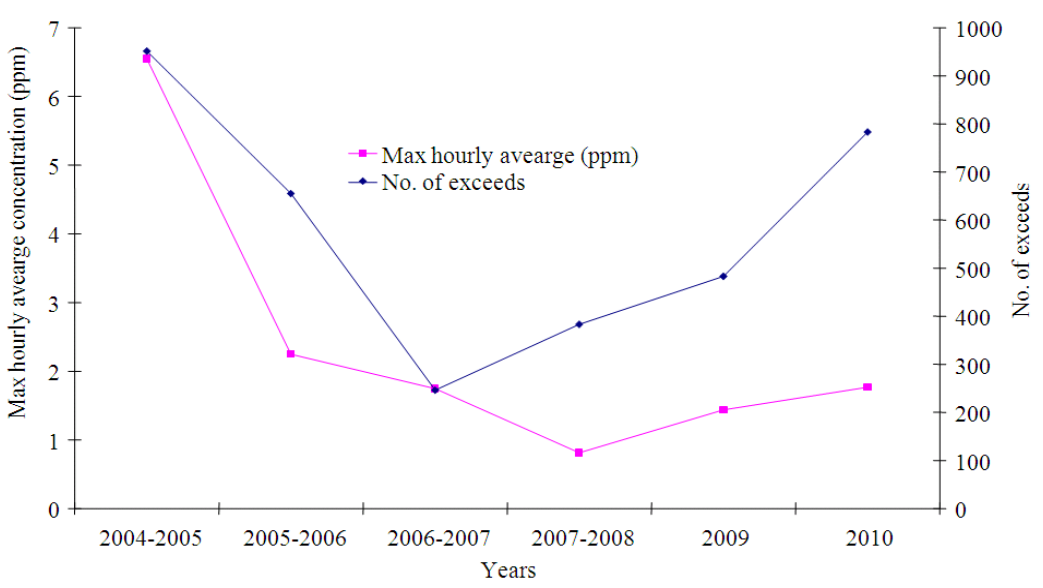

Fig. 6. Maximum hourly averages concentrations of $\mathrm{SO}_{2}$ and No. of Exceeds at ETC (2004-2010)

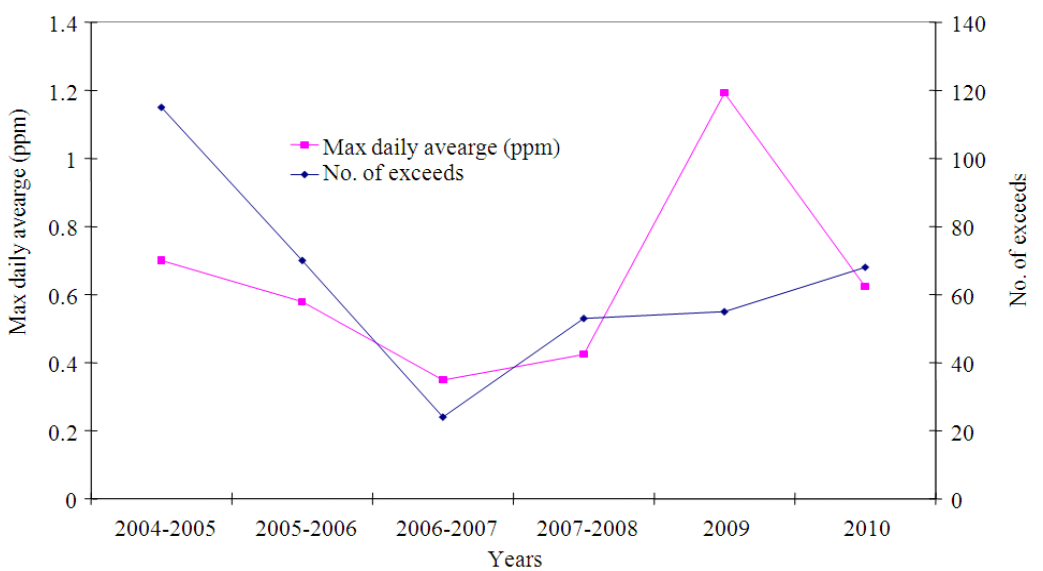

Fig. 7. Maximum Daily averages concentrations of $\mathrm{SO}_{2}$ and No. of Exceeds at ETC (2004-2010) 
Bassam A. Al-Helou / American Journal of Applied Sciences 9 (11) (2012) 1840-1848

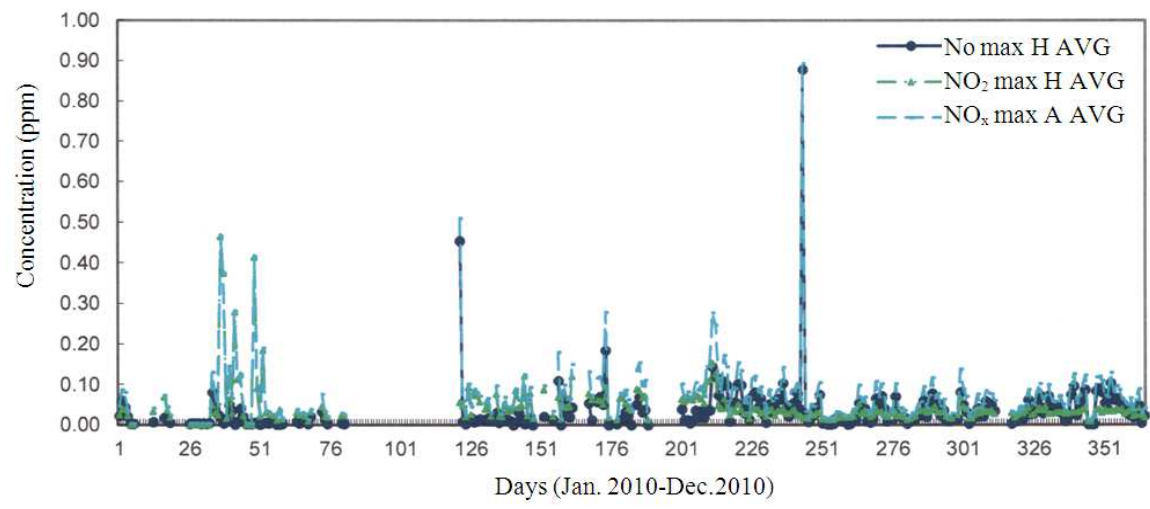

Fig. 8. Maximum hourly averages concentrations of $\mathrm{NO}, \mathrm{NO}_{2}$ and $\mathrm{NO}_{\mathrm{X}}$ at $\mathrm{ETC}$

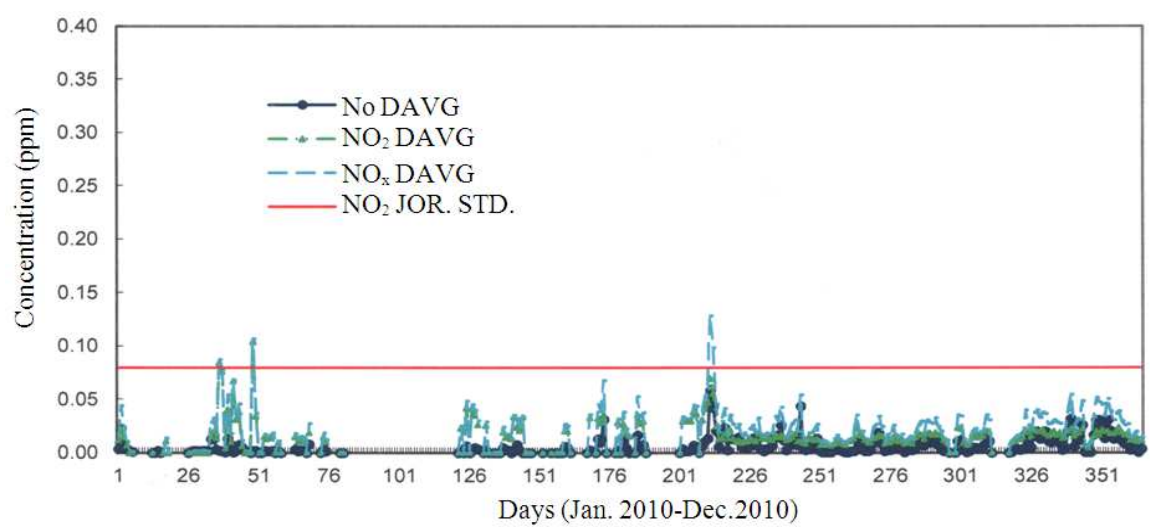

Fig. 9. Daily averages concentrations of $\mathrm{NO}, \mathrm{NO}_{2}$ and $\mathrm{NO}_{\mathrm{x}}$ at ETC
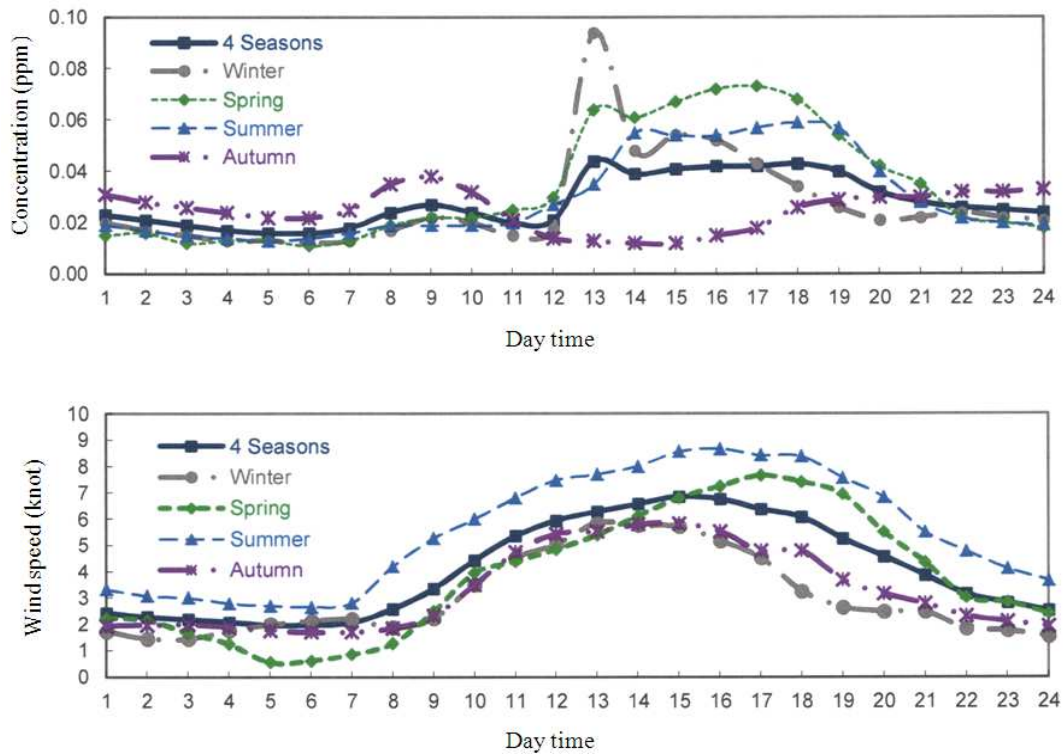

Fig. 10. Averages diurnal concentrations of $\mathrm{NO}_{\mathrm{x}}$ and wind speed diurnal average (knot) at ETC (ME, 2010) 


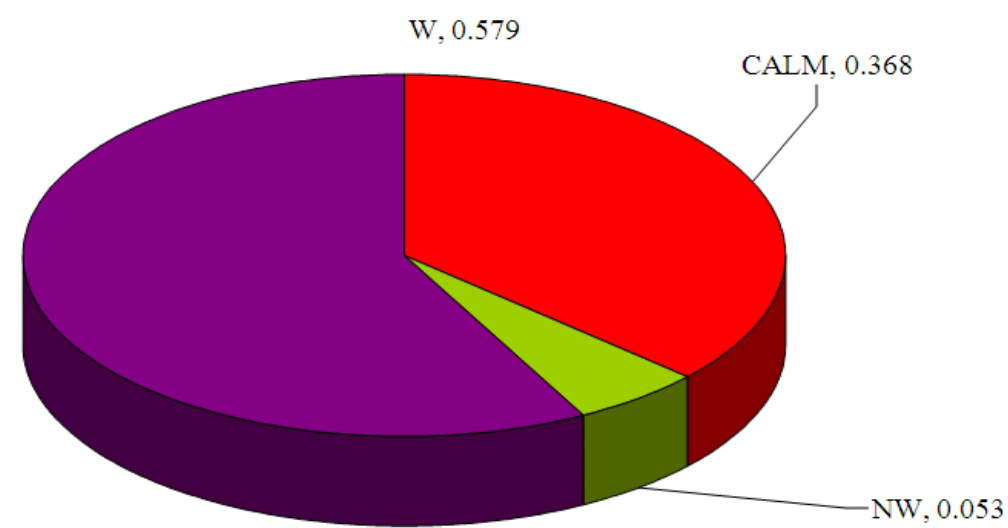

Fig. 11. Wind direction distribution during days at which $\mathrm{NO}_{2}$ daily average concentration exceeded JS limit of 0.08 ppm at ETC

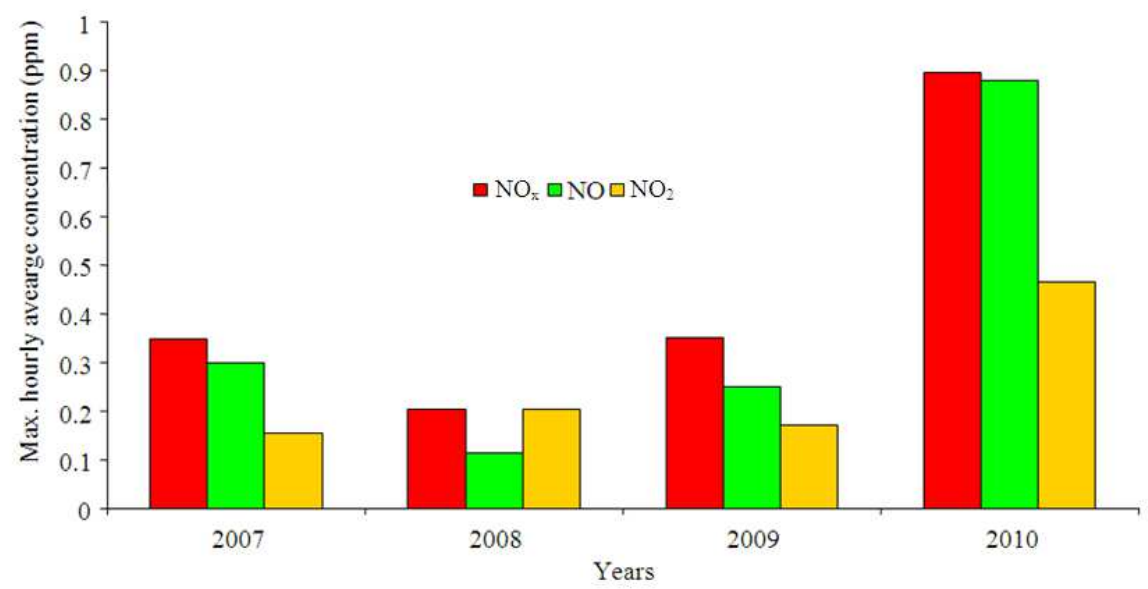

Fig. 12. Maximum hourly averages concentrations of $\mathrm{NO}, \mathrm{NO}_{2}$ and $\mathrm{NO}_{\mathrm{X}}$ at $\mathrm{ETC}(2007-2010)$

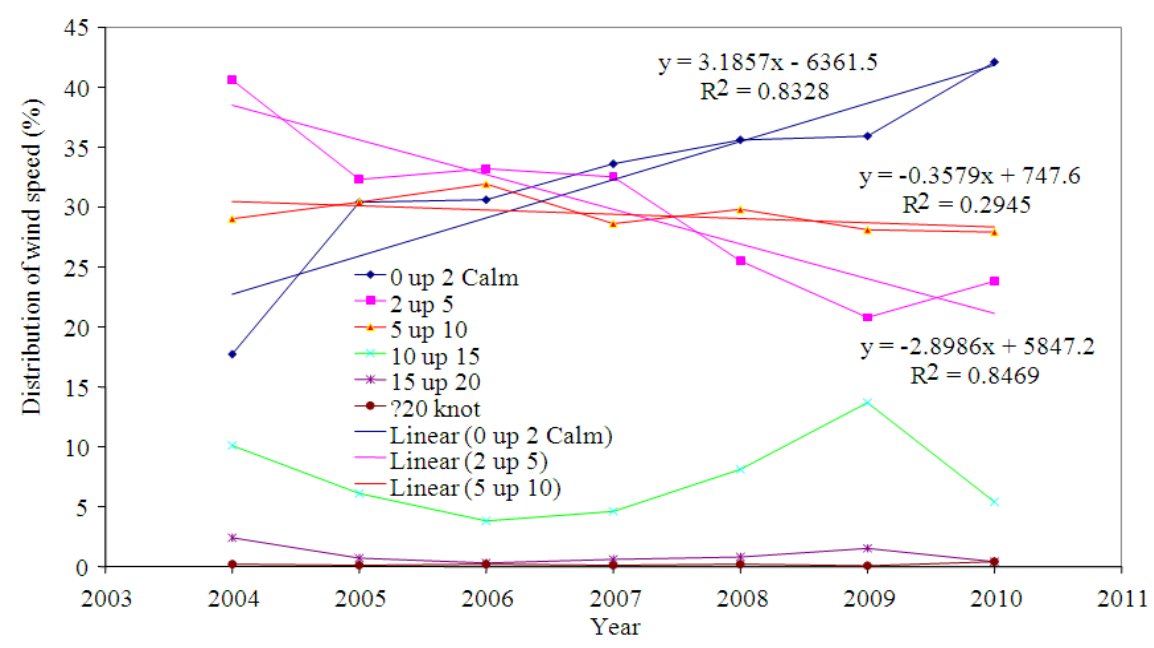

Fig. 13. Mathematical model of distribution wind speed (2004-2010) 
Bassam A. Al-Helou / American Journal of Applied Sciences 9 (11) (2012) 1840-1848

Table 2. Maximum Hourly averages of $\mathrm{SO}_{2}$ concentration (ppm) and percentage of wind direction

\begin{tabular}{|c|c|c|c|c|c|c|c|c|c|c|c|}
\hline Jan & Feb & Mar & Apr & May & Jun & Jul & Auq. & Sep. & Oct. & Nov. & Dec. \\
\hline 1.766 & 0.779 & 0.651 & 0.615 & 0.726 & 1.012 & 0.930 & 0.957 & 0.734 & 0.704 & 0.831 & 0.766 \\
\hline $\begin{array}{l}\text { Calm \% } \\
43.2 \\
\text { NW \% }\end{array}$ & 66.900 & 67.000 & - & 44.100 & 28.500 & 18.900 & 18.000 & 25.900 & 38.900 & 66.200 & 59.000 \\
\hline $\begin{array}{l}5.5 \\
W \%\end{array}$ & 6.300 & 5.500 & - & 18.400 & 25.500 & 45.600 & 11.300 & 0.000 & 23.200 & 3.000 & 4.800 \\
\hline 18.4 & 20.900 & 16.500 & - & 35.000 & 33.900 & 11.900 & 0.000 & 0.000 & 6.500 & 0.900 & 2.400 \\
\hline
\end{tabular}

Table 3. Maximum Hourly averages of $\mathrm{CO}, \mathrm{CO}_{2}$ and maximum 8-hours averages of $\mathrm{CO}$ concentrations (ppm)

\begin{tabular}{|c|c|c|c|c|c|c|c|c|c|c|c|c|}
\hline Pollutant & Jan & Feb & Mar & Apr & May & Jun & Jul & Auq. & Sep. & Oct. & Nov. & Dec. \\
\hline$\overline{\mathrm{CO}}$ & 0.397 & 1.487 & 0.546 & -- & 2.963 & 2.938 & 3.404 & 3.463 & 0.807 & 0.487 & 0.674 & 2.839 \\
\hline $\mathrm{CO}_{2}$ & 553.000 & 543.000 & 470.000 & -- & 802.000 & 865.000 & 941.000 & 994.000 & 473.000 & 372.000 & 410.000 & 445.000 \\
\hline \multicolumn{13}{|c|}{ Maximum 8-hours averages of CO concentration (ppm) } \\
\hline $\mathrm{CO}$ & 0.386 & 1.286 & 0.325 & -- & 1.149 & 1.08 & 1.708 & 1.370 & 0.474 & 0.160 & 0.351 & 1.065 \\
\hline
\end{tabular}

\subsection{Oxides (NO, $\mathrm{NO}_{2}, \mathrm{NO}_{\mathrm{x}}$ )}

The results of 2010 monitoring show that 15 excesses to the maximum hourly average of $\mathrm{NO}_{2}$, as defined by the Jordanian standards at $0.21 \mathrm{ppm}$. Figure 8 shows that the maximum averages of $\mathrm{NO}_{\mathrm{x}}, \mathrm{NO}$ and $\mathrm{NO}_{2}$ were 0.465 , 0.879 and $0.895 \mathrm{ppm}$ respectively. The first and second readings of the recording were carried in early September, while the third reading was done in February. Figure 9 shows the daily averages of Nitrogen oxides, where the maximum daily average of $\mathrm{NO}_{\mathrm{x}}$ was 0.129 ppm, NO $0.059 \mathrm{ppm}$ and $\mathrm{NO}_{2} 0.104$ ppm. Three excesses of $\mathrm{NO}_{2}$ to Jordanian standards were recorded.

Figure 10 explains the annual and seasonal averages of $\mathrm{NO}_{\mathrm{x}}$ concentration, as well as the wind speed per knot ( $\mathrm{knot}=1 \mathrm{~m} / \mathrm{s}$ ). It can be, accordingly, said that there is progressive harmony with the wind speed. Both factors attain their lowest level in the early morning and highest levels at the end of the day. Such a phenomenon can be indentified by analyzing a number of atmospherical factors that play a role in carrying emission to the monitoring sites. In addition, the speed and direction of the wind actually play an outstanding role in determining the distance that could be reached by emissions, as well as in the concentration of these emissions in the air.

Figure 11 shows the distribution of wind direction wherever excess to the daily average, as defined by Jordanian standards, is recorded at the monitoring site. The above emphasized conclusions confirm that AlHashimyeh area, lying to the east of JPR and HTPP, are gravely exposed to $\mathrm{NO}_{2}$ pollution when west and North West winds intensify. All together, winds accumulate to $63.2 \%$. Figure 12 indentifies the discrepancy between the results of 2010 monitoring and those of the previous years. It shows the values of the average nitrogen oxides between 2007 and 2010. The results prove the increase in the concentrations of these gases in 2010 as compared to the previous years. To understand this remarkable increase, the wind speed at Al-Hashimyeh area was analyzed for the years 2004-2010, after being divided in five speeds (0-2 knots). Eventually, those winds were labeled as calm winds, while the other winds were sorted out as 2-5, 5-10, 10-15 and $>20$ knots.

Analysis showed that calm wind was continuously increasing since 2004 up to 2010 and that the increase in 2010 was the highest compared to previous years. Indeed, this wind helps neither the dispersal no the reduction of gas emissions; on the contrary, it increases its concentration, especially in approximate areas to pollution sources. Math predictions warn of new increases during the coming years, owing to the increase in calm wind speed a year after year (Fig. 13).

Notice that math analysis proves that the mat model of calm winds increase is Equation 1:

$y=3.01857 x-6361.5$

$\mathrm{x}$ : stands for the year when calm wind is counted for, whereas the correlation value $\mathrm{R}^{2}=0.8328$, which is not low.

The math analyses also show that the (2-5 knots) and (5-10 knots) correspondently face decrease, as those analyses prove in the following two equations respectively Equation 2 and 3:

$$
\begin{aligned}
& y=-2.8986 x+5847.2 \\
& y=-0.3579 x+747.2
\end{aligned}
$$

The correlation value of $\mathrm{R}^{2}=0.8469$ and $\mathrm{R}^{2}=0.2945$. The latter value is not much. The high wind speeds 1520 knots and $>20$ knots have not been analyzed mathematically, due to their low proportion during the years of monitoring. 


\section{CONCLUSION}

This study has clearly shown that Al-Hashimyeh area is overwhelmed by calm winds and subsequently exposed to increasing gas pollution in the ETC. It has also come out with the fact that $\mathrm{SO}_{2}$ and nitrogen oxides have exceeded the limits of Jordanian standards, whereas carbon oxides maintained their low levels, with no record of violation of the standard limits. The study recommends the replacement of heavy fuel, which contains high degree of sulfur, by natural gas for power generation at HTPP.

Math analysis has shown the predicted the $\mathrm{NO}_{\mathrm{x}}$ increased pollution in the coming years, owing to the increased level of calm winds year after year. Such a fact helps the increase of these gas concentrations, especially in the approximate areas to pollution sources.

\section{ACKNOWLEDGEMENT}

The researchers would like to thank Jordanian Ministry of Environment for providing the air quality data necessary for this study.

\section{REFERENCES}

Al-Helou, B. and B. Sinokrot, 2004. Air quality comparison between industrial and residential communities. Environ. Ecol., 22: 586-591.

APPA, 1998. La pollution de lair: sources, effets, prevention, Association pour la Prevention de la Pollution Atmospherique. Ville de BesanconService Hygiene Sante, France.

Brunekreef, B. and S.T. Holgate, 2002. Air pollution and health. Lancet, 360: 1233-1242. DOI: 10.1016/S0140-6736(02)11274-8

Burki, D., J. Keller and B.E. Ga, 1994. Air pollution. Part 2: Concentrations of major air pollutants in Switzerland and trans boundary contributions. Paul Scherrer Institute, Switzerland.

DEAZ, 2005. Reports about al-hashimeya area. Directorate of Environment in Al-Zarqa.

$\mathrm{DH}, 2005$. Hydrogen Sulfide Chemical Information Sheet. Department of Health.

Fally, S., D. Joannes, D. Leduc and M. Scharll, 1995. La pollution, ses effets et ses Costs Special en region de Bruxelles-capitale. University Libre de Bruxelles, Belgique.

Hamdi, M.R., A. Bdour and Z. Tarawneh, 2008. Diesel quality in Jordan: Impacts of vehicular and industrial emissions on urban air quality. Environ. Eng. Sci., 25: 1333-1344. DOI: 10.1089/ees.2007.0234

HTPP, 2001. Report for air quality monitoring for the selected site of assamra power project at AlHashimeya.
Jol, A. and G. Kielland, 1997. Air pollution in Europe. European Environ. Agency.

JPRC, 2011. Jordan Petroleum Refinery Company (JOPT)-Financial and strategic SWOT analysis review. MarketResearch.

Kalabokas, P.D., L.G. Viras and C.C. Repapis, 1999. Analysis of the 11-year record (1987-1997) of air pollution measurements in Athens, Greece. part I: primary air pollutants. Global Nest: Int. J., 1: 157-167.

Lefohn, A.S. and D.S. Shadwick, 1998. Ozone, sulfur dioxide and nitrogen dioxide trends at rural sites located in the united states. Atmospheric Environ., 25: 491-501. DOI: 10.1016/0960-1686(91)90321-W

Mage, D. and O. Zali, 1992. Motor Vehicle Air Pollution: Public Health Impact and Control Measures. World Health Organization Division of Environmental Health. Switzerland.

Mbuyi, M.H.T., 2003. Air pollution at the bily kriz mountains in the czech republic. Int. J. Environ. Pollut., 19: 1-10.

ME, 2010. Study the levels of pollutants in the area of Al-Hashimeya. Unpublished Annual Report, Ministry of Environment.

Monroe, D. and W. Li, 2002. Desulafation dynamics of $\mathrm{NO}_{x}$ storage catalysts. Proceedings of the SAE Power Train and Fluid Systems Conference and Exhibition, (PTFSCE' 02), SAE International, San Diego, CA, USA. DOI: 10.4271/2002-01-2886

Odat, S., 2009. Diurnal and seasonal variation of air pollution at Al-Hashimeya Town, Jordan J. Earth Environ. Sci., 2: 1-6.

OPEC, 2005. Guide for petroleum product specifications. OPEC Organization.

Peters, A., H.E. Wichmann, T. Tuch J. Heinrich and J. Heyder et al., 1997. Respiratory effects are associated with the number of ultrafine particles. Am. J. Respiratory Critical Care Med., 155: 13761383.

Reay, M.E., 2004. Air quality and atmospheric pollution in the Arab Region. University of Alexandria.

Seaton, A., D. Godden, W. MacNee and K. Donaldson, 1995. Particulate air pollution and acute health effects. Lancet, 345: 176-178. DOI: 10.1016/S0140-6736(95)90173-6

WHO, 1979. Sulphur oxides and suspended particulate matter, environmental health criteria 8. World Health Organization, Geneva.

WHO, 2005. WHO Air quality guidelines for particulate matter, ozone, nitrogen dioxide and sulfur dioxide. World Health Organization. 